University of Pennsylvania Carey Law School

Penn Law: Legal Scholarship Repository

Faculty Scholarship at Penn Law

8-21-2011

\title{
Tying Arrangements and Lawful Alternatives: Transaction Costs Considerations
}

Herbert J. Hovenkamp

University of Pennsylvania Carey Law School

Follow this and additional works at: https://scholarship.law.upenn.edu/faculty_scholarship

Part of the Antitrust and Trade Regulation Commons, Economic Policy Commons, Industrial Organization Commons, Law and Economics Commons, and the Policy Design, Analysis, and Evaluation Commons

\section{Repository Citation}

Hovenkamp, Herbert J., "Tying Arrangements and Lawful Alternatives: Transaction Costs Considerations" (2011). Faculty Scholarship at Penn Law. 1863.

https://scholarship.law.upenn.edu/faculty_scholarship/1863

This Article is brought to you for free and open access by Penn Law: Legal Scholarship Repository. It has been accepted for inclusion in Faculty Scholarship at Penn Law by an authorized administrator of Penn Law: Legal Scholarship Repository. For more information, please contact PennlawIR@law.upenn.edu. 


\title{
Tying Arrangements and Lawful Alternatives:
}

\author{
Transaction Cost Considerations
}

\section{Herbert Hovenkamp}

\section{Introduction}

A tie-in might serve competition by promoting product quality and protecting the supplier's goodwill in the tying product. ${ }^{1}$ When the tying product works effectively only with ancillary materials or accessories or services of a particular quality, its supplier can assure the requisite quality of the ancillary product only by supplying that product itself. The cost savings defense and the defenses of quality control or good will are the most widely recognized and accepted tying defenses.

One characteristic of manufactured products is differentiation among the offerings of various brands. This in turn produces a need for more specialized provision of such things as supplies, aftermarket parts, and service. As a consequence firms often "dedicate" their production and organization to ongoing relationships with a narrow range of other firms. ${ }^{1}$ Franchising is an extreme case of this, where a McDonald's franchisee may be organized to do business exclusively with its franchisor. Tying is often a mechanism by which firms in such a relationship can carry out what amounts to a jointly contemplated business plan. Another result is that often firms simply cannot trust other firms to produce specialized goods that work well with the manufacturer's own equipment. Independent manufacturers may have a tendency to serve too many brands - for example, by making their printer cartridges compatible with numerous brands of printers - but such generic production may involve sacrifices in performance. In this case tying may become the mechanism by which a firm ensures that its own primary product plus aftermarket products will work together well. In this particular situation the transaction costs of dealing with others are too high in relation to the costs and benefits of simply producing for oneself. ${ }^{2}$

\footnotetext{
${ }^{1}$ See also 9 ANTITRUST II 1717 on consumer convenience or cost savings, which might also bear on the "quality" of the tying product. On the development of franchising and other organized distribution arrangements that included tying as methods of quality control, see Herbert Hovenkamp, The Law of Vertical Integration and the Business Firm: 1880-1960, 95 IOWA L. REV. 863, 884-87 (2009). See also Edward M. Iacobucci, Tying as Quality Control: A Legal and Economic Analysis, 32 J. LEGAL STUD. 435 (2003).

${ }^{1}$ See Oliver E. Williamson, The Mechanisms of Governance 59-70 (1996); Benjamin Klein, Robert G. Crawford \& Armen A. Alchian, Vertical Integration, Appropriable Rents, and the Competitive Contracting Process, 21 J.L. \& ECON. 297 (1978); Alan J. Meese, Tying Meets the New Institutional Economics: Farewell to the Chimera of Forcing, 146 U. PA. L. REV. 1 (1997); see also Edward Iacobucci, A Switching Costs Explanation of Tying and Warranties, 37 J. LEGAL STUD. 431 (2008).

${ }^{2}$ The argument is elaborated in Herbert Hovenkamp, Harvard, Chicago and Transaction Cost Economics in Antitrust Analysis, 55 ANTITRUST BULL. 613 (2010), available at http://papers.ssrn.com/sol3/papers.cfm?abstract_id=1592476.
} 
What virtually all of these situations have in common is that they occur in markets that involve differentiated, typically branded products and fairly specialized aftermarket products or services. Although the variations are too numerous for comprehensive discussion here, the following examples are typical. IBM once insisted that users of its data processors of the 1930s use only its blank cards (on which users punched holes representing data) on the ground that the machine would malfunction with cards that were too thick or dirty. ${ }^{3}$ General Motors once insisted that its dealers use only GM-made repair parts on the ground that other parts would impair the auto's functioning or durability, for which consumers would blame GM. ${ }^{4}$ In the 1950s, Jerrold Electronics installed its rural cable television systems without additional charge in order to assure their proper functioning, purchaser satisfaction, and hence the manufacturer's reputation. ${ }^{5}$ Microsoft claimed that its bundling of the Internet Explorer (IE) browser and the Windows operating system made it easier for third-party software developers to develop programs for Windows, because they could anticipate that unique IE interfaces would already be installed and did not have to be reproduced on each software program; further, these benefits could not be obtained via design specifications. ${ }^{6}$

Similarly, a manufacturer of a complex or delicate machine may, in effect, require users to have the machine serviced by the manufacturer's own representatives. The manufacturer might fear that outside repairers would damage the machine in ways that the manufacturer could not prove to be attributable to faulty service. The reputation of the machine may suffer, and the manufacturer may even have to bear the cost of restoring the machine. Such service by the manufacturer may also be the means for learning about operating problems of the tying and tied products and adjusting or improving them. Reputation may also be at stake when fast-food franchisors insist upon supplying franchisees with the spices and pizza dough, generating the distinctive flavor or quality that consumers associate with the franchisor's trademark. ${ }^{7}$ As a result tying

${ }^{3}$ IBM Corp. v. United States, 298 U.S. 131, 134 (1936) ("To insure satisfactory performance by appellant's machines it is necessary that the cards used in them conform to precise specifications as to size and thickness, and that they be free from defects due to slime or carbon spots, which cause unintended electrical contacts and consequent inaccurate results"; tie condemned).

${ }^{4}$ Pick Mfg. Co. v. Gen. Motors Corp., 80 F.2d 641 (7th Cir. 1935), aff'd per curiam, 299 U.S. 3 (1936) (insufficient effects); Gen. Motors Corp., 34 F.T.C. 58 (1941) (illegal).

${ }^{5}$ United States v. Jerrold Elec. Corp., 187 F. Supp. 545 (E.D. Pa. 1960), aff'd per curiam, 365 U.S. 567 (1961) (tie illegal though once justified).

${ }^{6}$ United States v. Microsoft Corp., 253 F.3d 34, 90 (D.C. Cir.), cert. denied, 534 U.S. 952 (2001). The court did not pass judgment on these claims but used them as a basis for deciding that the tie should be remanded for consideration under the rule of reason. The government subsequently dropped the tying claim. (To the extent it is relevant, H.H. was consulted by the federal and some state governments.)

${ }^{7}$ E.g., Siegel v. Chicken Delight, 448 F.2d 43 (9th Cir. 1971), cert. denied, 405 U.S. 955 (1972) (illegal tie). See also Queen City Pizza v. Domino's Pizza, 124 F.3d 430 (3d Cir. 1997), cert. denied, 523 U.S. 1059 (1998) (tie necessary to maintain product uniformity and consistency across franchises); Krehl v. Baskin-Robbins Ice Cream Co., 664 F.2d 1348, 1354 (9th Cir. 1982) (sale of substandard products under the company trademark would dissipate goodwill and reduce the value of the mark); Little Caesar Enters. v. Smith, 34 F. Supp. 2d 513 (E.D. Mich. 1998) (similar); Collins v. Dairy Queen, 939 F. Supp. 875 (M.D. Ga. 1996) (rejecting defendant's argument that franchisor approval of products and suppliers was essential to quality control). 
products from a particular source or of a particular quality is often associated with arrangements that involve trademark licensing, such as franchises. ${ }^{3}$ Or a hospital may make its operating rooms safe and effective by insisting that patients use only the highly qualified anesthesiologists it employs. ${ }^{8}$

In these examples, the tie-in allows the supplier of a tying product (tabulator, computer operating system, auto, cable system, machine, trademark, or operating room) to protect its quality against the degradation that would result from use of an inferior or incompatible tied product (cards, Internet browsers, parts, installation, service, spices or other consumable ingredients, or unqualified anesthesiologists, respectively). Promoting quality benefits the purchaser and, thereby, the supplier's own reputation and future sales.

The kind of tie that might be justified or the kind of less restrictive alternative that might be preferable varies with the exact contours of the quality-control claim. Consider a defendant who wishes to observe closely the tying (or tied) product's operation and failures in actual use in order to improve it or the ancillary products that work with it. Product improvement is certainly a legitimate end. To achieve it, the defendant requires users of the tying product to take a second product. For on-site observation of the tying product, the tied product would be repair service, which has perhaps been bundled into the tying-product price. If the performance of certain repair parts or ancillary materials or attachments is at stake, the defendant may insist that they be purchased from the defendant, to be returned for study after wearing out or failing.

While most products might be further improved by closely examining their actual operations and failures, this possibility could not account for a tie when returned items were not in fact studied or when service records were not written or collated to assist product design or manufacture. Perhaps the necessary costs of implementing those steps would themselves discourage attempts to disguise a tie with insincere examinations and studies.

A product-improvement claim may be genuine and yet be attainable in a less restrictive way. When users are numerous, perhaps subjecting a sample (especially a large sample) of them to the tie is likely to provide all the data needed by a reasonable product improver. When users are not so numerous, an adequate sample would include a larger portion of them. Although collection of data from outside suppliers of the goods or services would be even less restrictive, that route is likely to be less flexible and more costly than subjecting an appropriate portion of the users to the tie.

\section{Asset Specificity and Quality Control as Defense}

A tie might be used by a defendant with no power in the tying market and with no purpose or effect of gaining power in the tied market or even of exploiting customers. While quality control certainly provides no ground for opposing tie-ins, let us assume a

\footnotetext{
${ }^{3}$ See Dan L. Burk \& Brett H. McDonnell, Trademarks and the Boundaries of the Firm, 51 WM. \& MARY L. REV. 345 (2009).

${ }^{8}$ Cf. Jefferson Parish Hosp. Dist. No. 2 v. Hyde, 466 U.S. 2 (1984) (hospital provided patients only with anesthesiologists it had selected).
} 
tie that is prima facie unlawful on other grounds, and then consider when quality control should count toward its redemption. Of course, to the extent that any of the previous examples do not present two separate products, they would be untouched by anti-tying law and thus would require no defense for quality control or goodwill. ${ }^{4}$ Installation (especially when without extra charge) may seem inseparable from the machine itself, as might the spices creating the taste that defines a food trademark, or the bundle of services that constitute a hospital or arguably even the specialized combination of a complex machine plus servicing. Indeed, some decisions expressly declare that the justification for a business practice bears on whether to classify it as a tie. ${ }^{9}$ In Microsoft the D.C. Circuit appeared to reject this position, but did hold that the possibility of significant efficiencies justified applying the rule of reason rather than the per se rule to Microsoft's tie of its computer operating system and browser. ${ }^{10}$

Finally, some variations negate prima facie illegality and thus dispense with any need for justification. For example, requiring one's customer to take a second product only from numerous "approved sources" in which the defendant has no economic interest falls outside the tying category altogether. ${ }^{11}$

Problematically, many of the litigated ties have involved foreclosure of only a minuscule portion of the tied market. Requiring a significant foreclosure before finding prima facie illegality would often obviate the many vexing questions concerning either cost savings or quality control. Asset specificity is ubiquitous, and serves to explain ties in many competitive markets, including franchising, office equipment, and medical services to name a few. A non-foreclosing tie ordinarily has no anticompetitive effects. Under a rule of reason treatment no justification would be required for legality, but even under harsher treatment even a modest inference of quality protection should defend the tie.

In short, all the issues that must be separated for clear exposition are interconnected. The narrower the definition of a single product, the broader the concept of a tie-in; and the fewer the effects required for prima facie illegality, the greater is the warrant for allowing a quality control defense and for giving it wider scope. Put another way, when quality control is genuinely at stake, we should hesitate to require the defendant to take the less restrictive route of disclosing a trade secret (even with compensation) or possibly diluting its trademark, ${ }^{12}$ unless a serious foreclosure is also at stake. However, all those issues are reconnected later in the chapter. Here we

\footnotetext{
${ }^{4}$ On the requirement of separate products, see Ch. 17D-1.

${ }^{9}$ E.g., Hirsh v. Martindale-Hubbell, 674 F.2d 1343, 1347 (9th Cir.), cert. denied, 459 U.S. 973 (1982). See also Jack Walters \& Sons Corp. v. Morton Bldg., 737 F.2d 698, 703 (7th Cir. 1984) (single product if there are "rather obvious economies of joint provision"); see 10 ANTITRUST III 1741-1745 (discussing this definition).

${ }^{10}$ Microsoft, 253 F.3d at 86-88; see Herbert Hovenkamp, IP Ties and Microsoft's Rule of Reason, 47 ANTITRUST BULL. 369 (2002).

${ }^{11}$ See 9 ANTITRUST II 1726. When the defendant collects a fee for approving a supplier, see 9 ANTITRUST II $1727 \mathrm{~d}$.

${ }^{12}$ E.g., Krehl v. Baskin-Robbins Ice Cream Company, 664 F.2d 1348 (9th Cir. 1982), where the franchisees wanted to substitute their own ice cream for Baskin-Robbins' trademarked brand.
} 
assume prima facie illegality and ask whether and how a quality control defense should be analyzed.

\section{Protection of Quality and Goodwill}

Protecting quality and its attendant goodwill seems undeniably legitimate, as it benefits consumers as well as the producer. As usual, however, asserting a qualityprotection defense does not itself establish it, for the challenged tie may in fact serve a different function. Hence, the defendant must show how the tie actually promotes quality and protects goodwill. Even when the quality of the second product affects the functioning of the tying product. Users will also want to guard against malfunctions of the tying product. Users thus tend to choose qualified second products though they are not compelled by a tie-in to do so. In this sense, quality may be self-protecting, at least once the defendant has informed users of the necessary features.

When quality does not thus protect itself, a customer's promise to use a second product that complies with specifications issued by the defendant is less restrictive than a promise to buy the product from the defendant. The discussion below examines the adequacy and administrative costs of implementing such compulsory specifications, which are generally lawful.

When mere specifications, whether voluntary or compulsory, are ineffective or too costly, there remains another alternative to the conventional tie: allowing the customer to take the second product from anyone providing appropriate quality, as certified by the defendant. This "alternate source" option is genuine when the defendant appraises other products in good faith. The defendant may demand reimbursement for the costs of inspection. Under existing doctrines, however, it may not charge merely for access to the restrained customers or limit the number of approvals for its own sake. When disclosure of specifications to customers or rivals involves significant trade secrets defendants should not be required to create new competition for a second product at all. Further, a defendant choosing to license its intellectual property may charge appropriate royalties.

Many decisions, including several by the Supreme Court, have rejected qualitycontrol defenses because the challenged tie did not seem necessary to protect quality. In one of those cases, however, the Court spoke in terms that might seem to reject such a defense in principle even if a tie uniquely solved a genuine quality-control problem. In condemning a tie of punch cards under Clayton Act §3, notwithstanding a claim that thin and clean cards were necessary for effective operation of the defendant's tabulating machine, the Court made this apparently categorical statement:

The Clayton Act names no exception to its prohibition of monopolistic tying clauses. Even if we are free to make an exception to its unambiguous command ... we can perceive no tenable basis for an exception [where goodwill is either not at stake or is protectable in a less restrictive way]. ${ }^{13}$

\footnotetext{
${ }^{13}$ IBM Corp. v. United States, 298 U.S. 131, 140 (1936).
} 
Notwithstanding the "no exception" and "unambiguous command" language, the holding was that IBM failed to establish a defense, even if one existed. At the ellipsis, moreover, the Court cited several lower court cases allowing tie-ins.

In all events, the lower courts have consistently recognized the legitimacy of protecting quality. They have done so through several routes. Some weighed the business justification in the course of determining whether the challenged transaction involves two products or only one. ${ }^{14}$ Other courts explicitly absolved an otherwise illegal tie on the ground that it protected product quality. In addition, some courts recognize the legitimacy of quality control while holding that a particular defendant failed to show a significant quality problem in fact or that an adequate and less restrictive solution was available to the defendant. Finally, the D.C. Circuit held in Microsoft that product quality demands justified jettisoning the per se rule and applying a full rule of reason in the particular case of computer operating system/applications ties. ${ }^{15}$

\section{Quality Control Sufficiently Protected by Consumer Choice?}

Naturally, most buyers want the tying product to function well. IBM customers surely wanted accurate tabulating. Cable TV operators could not prosper without a properly installed system. Repeat patronage for auto dealers or fast-food franchisees would suffer when consumers receive poor repairs or food untrue to the trademark. And consumers surely want satisfactory anesthesia.

Why then does the supplier of the tying product need to compel its customers to take a superior tied product instead of inferior (though less expensive) ${ }^{16}$ substitutes? Answering that question may vary with the tied buyer's knowledge of the products and the buyer's place in the distribution chain, as well as the life cycle and reputation of the tying product.

\section{Buyer Alone at Risk}

When the buyer alone bears the full consequences of diminished performance, it will presumably buy the second product with the best price-quality combination for its purposes. If such a buyer overweighs a bargain price for an unduly inferior product and reaps unhappy results, no one else can be harmed or blamed. Hence, in this situation, the seller's only interest, if any, is to inform the buyer of product characteristics -in the IBM example, the specifications for thin and clean cards that IBM machines can tabulate accurately. ${ }^{17}$ While IBM might exaggerate the quality difference between its cards and those of rivals, or the inaccuracies occasioned by thick or dirty cards might be

${ }^{14}$ E.g., Jack Walters \& Sons Corp. v. Morton Bldg., 737 F.2d 698 (7th Cir. 1984); Krehl v. BaskinRobbins Ice Cream Co., 664 F.2d 1348 (9th Cir. 1982).

${ }^{15}$ United States v. Microsoft Corp., 253 F.3d 34, 90 (D.C. Cir.), cert. denied, 534 U.S. 952 (2001).

${ }^{16}$ The purchaser would seldom, if ever, buy an arguably inferior version of a product unless it were cheaper. To be sure, a physically inferior product is economically superior when its diminished-use value to the buyer is less than its price discount.

${ }^{17}$ The Supreme Court assumed that this was the situation and rejected quality-control justifications in IBM Corporation v. United States, 298 U.S. 131 (1936), and in International Salt Company v. United States, 332 U.S. 392 (1947). 
acceptable to the user, the user that disregards IBM's advice has only itself to blame for any disappointing results.

The defendant's stake in quality control is also minimal when it can readily be disclaimed. In Data General, for example, the defendant made computers and a software system that operated them. ${ }^{18}$ Not sold for use with other computers, the software could be obtained only by taking the defendant's computers. The court found a tie that was not adequately redeemed by the defendant's explanation that the software was designed to function solely with its own computers and could malfunction when used with at least some computers made by others (including the plaintiff). In that event, the defendant's warranty of properly functioning software would require unduly expensive field testing to identify the other computer's characteristic that caused the malfunction and to revise the software accordingly. To the court, those costs seemed self-inflicted, because the defendant might simply limit its warranty with respect to software used with other computers. ${ }^{19}$

The Fourth Circuit replied similarly to Mercedes-Benz's fear that consumers or dealers might fraudulently claim warranty service on non-Mercedes parts that looked like the real thing. ${ }^{20}$ The court doubted that Mercedes would often be unable to identify its own allegedly superior parts and suggested that Mercedes could readily mark its own products to make them uniquely identifiable and thus escape fraudulent claims without requiring dealers to purchase all parts from Mercedes.

\section{Seller Also at Risk}

More is at stake when the seller also suffers from the buyer's erroneous choice of an unduly inferior version of the tied product. Suppose, for example, that the IBM tabulating machine had been a new product that had not yet established itself in the market. If too many buyers used inferior cards that they erroneously believed to be thin and clean enough, the machine might acquire a reputation for inaccuracy or quirkiness that would discourage use or even ruin the product. Moreover, users might be deceived by apparently trustworthy providers of supplies or services who blamed the machine.

The Jerrold court saw just such a situation. ${ }^{21}$ Jerrold made devices for bringing in remote television broadcast signals to smaller towns that otherwise enjoyed no television stations or reception. At the outset, Jerrold sold the equipment outright to system operators, who arranged installation by Jerrold or others. Often organized with limited funds, some operators purchased the equipment on credit and chose cheaper but, as it turned out, inadequate installation from others. When such operators failed to

\footnotetext{
${ }^{18}$ Data Gen. Corp. Antitrust Litig., 490 F. Supp. 1089 (N.D. Cal. 1980) (defense not established), ultimately condemned, 734 F.2d 1336 (9th Cir. 1984), cert. denied, 473 U.S. 908 (1985).

${ }^{19}$ Whether such a limit on a warranty might itself amount to a tie-in is explored in 10 ANTITRUST IIII 1740c5, 1744f, 1749d.

${ }^{20}$ Metrix Warehouse v. Daimler-Benz, 828 F.2d 1033 (4th Cir. 1987), cert. denied, 486 U.S. 1017 (1988).

${ }^{21}$ United States v. Jerrold Elec. Corp., 187 F. Supp. 545, 556-557 (E.D. Pa. 1960), aff'd per curiam, 365 U.S. 567 (1961); see also Queen City Pizza v. Domino's Pizza,_124 F.3d 430, 440-41 (3d Cir. 1997) (noting in dicta that quality control may justify franchise ties).
} 
prosper, Jerrold went unpaid ${ }^{22}$ and many observers doubted the quality of cable television systems, jeopardizing further sales by Jerrold. In response, Jerrold included installation in the sales price of its equipment and thus, in effect, required operators desiring the "tying" equipment to purchase "tied" installation service from Jerrold as well. Though legally free to purchase such service elsewhere, operators would naturally take the installation that was already "bundled" into the equipment price.

The court held that Jerrold had presented a compelling defense that its survivalindeed that of the new industry it had created-depended upon the tie-in, and that such alternatives as specifications and advice had already been proven inadequate. However, the court limited that defense to Jerrold's pioneering phase. As the cable TV concept and its implementing equipment were well established at the time of suit, the court held that Jerrold's reputation was no longer at stake. If new installations did not work properly, the market would understand that the failure lay with the installer rather than with Jerrold's equipment. ${ }^{23}$

\section{Free-rider Problems: Intermediate Buyer Transfers Risk of Poor Quality to Others}

The threat to the seller is even greater when the buyer is an intermediate party who gains immediately by paying less for any inferior product while suffering relatively little from the inferior performance. If even the best fast-food franchisee adjacent to a tourist attraction receives no repeat patronage-to take an extreme example-its business volume depends not on its own quality but on the goodwill generated by each tourist's hometown franchisee. That tourist area franchisee may increase profits by using inferior ingredients; it enjoys all the savings while fellow franchisees elsewhere bear all the loss in the product's reputation. Similarly, a gas station serving only transients might sell inferior accessories (such as oil) along with a well-known brand of gasoline that attracts the customers. ${ }^{24}$

A more complex situation is the branded automobile dealer who repairs cars with parts made by a different manufacturer. For example, a Mercedes dealer uses cheaper-and, Mercedes would say, inferior-parts made by someone else. The dealer probably claims that the parts it uses are just as good or, perhaps, that any superiority of the auto maker's parts is superfluous "gold plating." The manufacturer, on the other hand, claims that its repair parts are better and, in the case of luxury cars, that superperfection and reliability are not superfluous; they are the essence of the luxury

${ }^{22 ، " M a n y ~ o p e r a t o r s ~ w e r e ~ n o t ~ i n ~ a ~ p o s i t i o n ~ t o ~ p a y ~ c a s h ~ f o r ~ t h e ~ n e c e s s a r y ~ e q u i p m e n t ~ a n d ~ t h e ~ r i s k s ~ w e r e ~}$ such that outside financing could not be obtained. Therefore, payment was often contingent on the success of the system." Id. at 556.

${ }^{23}$ The court did not consider whether Jerrold, after it became well established, still bore severe risks on credit sales to operators who would be unable to pay if faulty installation impaired their success and revenues.

${ }^{24}$ For a more complex illustration of free riding that could interfere with quality, see 9 ANTITRUST II $1717 f 1$ (hospital anesthesiologists). 
product. ${ }^{25}$ Although consumer dissatisfaction impairs the product's reputation and the repeat business of both dealer and manufacturer, the manufacturer's long-term stake in product goodwill is greater, and the dealer may have some transient victims who would not return for repairs or new cars in any event.

\section{Pioneering Versus Established Products}

The Mercedes example takes us back to Jerrold and its distinction between pioneering and well-established products. That case permitted installation service to be tied to rural cable TV systems only until Jerrold had proven that its product worked well. The court recognized that it could not identify the day or year when the defense expired $^{26}$ and thus highlighted the uncertain boundary between a well-established product of secure repute and a pioneering product not yet widely accepted as reliable. But is a reputation ever that secure? Though Mercedes is well established and apparently successful, every inferior repair part used by a dealer can lose future sales to the immediate customer and perhaps her acquaintances as well. Strong positions are not impregnable, especially in luxury products.

At most, therefore, the pioneering-established distinction seems appropriate only when the manufacturer's customer would itself suffer the primary loss from using an inferior substitute for the tied product. In Jerrold the cable operator itself would suffer greatly, if not fatally, from improper installation. In the Mercedes example, some dealers might think they would not be injured significantly by using moderately inferior repair parts. If so and if the product then works less well for the consumer, the product's reputation tends to erode-perhaps slowly but probably cumulatively. Because this seems the typical, not the extraordinary, consequence of inferior repair service, the manufacturer's interest in proper repairs seems legitimate and forceful-more so in the case of pioneering products, but not exclusively there. Whether a tie-in is needed for that purpose is the next question.

\section{Published or Other Manufacturer Supplied Specifications as an Alternative}

Assuming that a second product's quality significantly affects that of a first product and the defendant's goodwill, as in the previous examples, is the defendant able to ensure proper quality control by its customer without a tie requiring the customer to buy the second item from the same source? The least restrictive route is education via published specifications for the second product. The defendant might simply publish the specifications of the second product: the thickness and cleanliness of the punch cards, the repair parts, detailed installation and service manuals, the flavorings and ingredients of a fast food, or even "how to identify a good anesthesiologist." Such specifications may thus appear to be less restrictive alternatives to tie-ins.

Of course, no alternative would be less restrictive if the defendant successfully

\footnotetext{
${ }^{25}$ Of course, either the dealer or the manufacturer might be "exploiting" consumers - dealers by pocketing the savings from using alternative parts, or manufacturers by attempting to force unnecessarily high-priced parts on dealers and consumers.

${ }^{26}$ Jerrold, 187 F. Supp. at 558.
} 
shows that mechanically necessary equipment of like quality and design are not available from any other source. ${ }^{27}$ However, "Once there is a competitor who can supply the tied items in the same quality class as the original vendor, the justification of a tying arrangement to protect the industry name evaporates." ${ }^{8}$ The quoted statement assumes, of course, that the alternatives of requiring specifications or approvals of other sources can adequately protect quality. While such alternatives are equally adequateand the tie equally superfluous-before any equivalent supplier arrives, the alternatives are no less exclusionary than a tie when no one else can meet specifications or gain approval. In that event, neither customers nor would-be rivals are injured, even though society might prefer the alternatives as more hospitable to equivalent suppliers if and when they arrive.

The Supreme Court certainly thought so in the International Salt case. ${ }^{29}$ International Salt had provided food canners with a patented machine to dispense measured amounts of salt into cans moving along a production line. Customers were allowed to use the machine only with salt purchased from International, which explained that its 98.2 percent pure salt assured proper functioning of the machine and minimized repairs for which it was responsible. Rival salt was allegedly less consistent and "in many instances" was only 95 percent pure. ${ }^{30}$ Assuming arguendo that the machines worked best with salt of 98.2 percent purity, the Court said that canners might be required to use only salt meeting such a specification of quality. "But it is not pleaded, nor is it argued, that the machine is allergic to salt of equal quality produced by anyone except International." 31 Moreover, quality control did not seem to be the true function of the tie, for the defendant did not specify the source or quality of salt used with the machine in regions where it sold no salt. ${ }^{32}$

The Court had taken the same approach in its earlier IBM decision: even if IBM's tabulating machines might malfunction without clean and thin cards, "There is no contention that others ... cannot meet these requirements. It affirmatively appears, by stipulation, that others are capable of manufacturing [suitable] cards." ${ }^{33}$

As the Supreme Court summed up in Jefferson Parish,

We have ... uniformly rejected ... goodwill defenses for tying

\footnotetext{
${ }^{27}$ See United States v. Mercedes-Benz of N. Am., 517 F. Supp. 1369, 1388 (N.D. Cal. 1981) (rejecting defendant's argument that use of unauthorized parts would lead to customer dissatisfaction and dangerous safety problems leading to massive tort exposure; court: "if a manufacturer's brand of the tied product is in fact superior to that of competitors, the buyer will presumably choose it anyway."). In United States $v$. Microsoft Corporation, 253 F.3d 34, 90-91 (D.C. Cir.), cert. denied, 534 U.S. 952 (2001), the problem as Microsoft stated it was not so much the quality of alternative browsers but the uniqueness of their application program interfaces (API's), or interfaces that computer software developers need for their software to invoke the Internet or collateral capabilities.

${ }^{28}$ Carpa v. Ward Foods, 536 F.2d 39, 47 (5th Cir. 1976).

${ }^{29}$ Int'l Salt Co. v. United States, 332 U.S. 392 (1947).

${ }^{30} I d$. at 397.

${ }^{31} I d$. at 397-398.

${ }^{32}$ See John L. Peterman, The International Salt Case, 22 J.L. \& ECON. 351, 360 (1979).

${ }^{33}$ IBM Corp. v. United States, 298 U.S. 131, 139 (1936).
} 
arrangements, finding that the use of contractual quality specifications are generally sufficient to protect quality without the use of a tying arrangement. ${ }^{34}$

The Court did not have to face the quality issue in that case because there were no findings below "as to why contractual quality specifications would not protect the [tying defendant]." ${ }^{35}$ Further, the Court was not stating this conclusion as a matter of law, for clearly the sufficiency of quality specifications in a particular instance presents a question of fact. The Court was saying only that this particular goodwill defense was seldom or never recognized in the historical cases.

Accordingly, defendants offering a quality-control defense have been required to rebut the adequacy of specifications as a less restrictive protection of quality by showing that specifications cannot be reasonably articulated or that monitoring and enforcement of compulsory specifications are too costly or are ineffective. Disclosure may also have the effect of surrendering trade secrets without compensation.

In any event, requiring courts to evaluate claims or defenses about the adequacy of a rival's alternative to the tied goods, such as aftermarket parts, places upon them a substantial burden. Often these arrangements are worked out among firms after many years of trial and error, and courts cannot possibly substitute their judgment effectively for those of the parties themselves. As we have noted previously, this makes it imperative that the judicial obligation arise only when a tie is clearly exclusionary on other grounds, and not simply prima facie illegal under a rule that does not insist on real proof of anticompetitive foreclosure.

\section{Adequate Articulation}

It is not always possible to articulate specifications that capture the essence of product quality or that can be understood and applied by immediate or ultimate users. Accordingly, the courts have consistently declared that the alternative is not required where mandatory specifications for a substitute would have to be so complex and detailed that they could not practicably be supplied or administered. ${ }^{36}$ Installation of a complex product, especially if new, illustrates the point, for a manual could be complete enough only with actual training and supervision. More clearly, specifications are impractical when the requisite quality depends on the franchisor's taste, which cannot readily be expressed in a formula or recipe. Thus, a coffee supplier was allowed to require restaurant franchisees bearing its name to buy its ground coffee, which was blended according to its taste, and the goods the supplier baked itself, but not goods

\footnotetext{
${ }^{34}$ Jefferson Parish Hosp. Dist. No. 2 v. Hyde, 466 U.S. 2, 26 n.42 (1984) (citing International Salt, IBM, and dicta in Standard Oil Co. v. United States, 337 U.S. 293, 305-306 (1949) ("The only situation ... in which the protection of good will may necessitate the use of tying clauses is where specifications for a substitute would be so detailed that they could not practicably be supplied.").

${ }^{35}$ Jefferson Parish, 466 U.S. at 26 n. 46.

${ }^{36}$ See, e.g., Susser v. Carvel, 332 F.2d 505, 515 (2d Cir. 1964), cert. dismissed, 381 U.S. 125 (1965) (providing detailed specifications for ice cream flavors in advance would be very difficult); see also United States v. Mercedes-Benz of N. Am., 517 F. Supp. 1369, 1388 (N.D. Cal. 1981).
} 
that were produced by licensees. ${ }^{37}$

By this reasoning, a soft-ice cream franchisor was denied this defense when it failed to show that specifications would have to be so complex and detailed as to make them impractical. ${ }^{38}$ Other franchisors were also denied the defense after a jury concluded that their goodwill interest in uniformly tasting chicken or seafood dinners made by franchisees could be satisfied without a tie of flavorings or other ingredients. ${ }^{39}$ Similarly, an automobile distributor was preliminarily denied a defense for requiring dealers buying its cars to take delivery service arranged by the distributor. ${ }^{40}$ Although timely delivery was needed to please consumers, the court supposed that many carriers could supply that service once the defendant specified delivery requirements. On the same grounds, a cemetery was not allowed to insist that those buying its burial lots also take its grave markers. ${ }^{41}$ Although the cemetery's responsibility for perpetual care established a legitimate interest in attractive and durable markers, many markers made by others could satisfy any reasonable specifications for those ends, and the cemetery could exclude those that did not. While specifications for "foundation preparation and memorial placement" might have been harder to frame, a similarly situated defendant was unable to persuade the court that "the system of competition will become unmanageable and that the foundations prepared or markers installed by their private competitors will detract from the appearance or decrease the general services rendered the public." 42 Specifications were not shown to be impractical. ${ }^{43}$

The adequacy of a less restrictive alternative has often been left to the jury. ${ }^{44}$ But where experience actually demonstrates the inadequacy of advice (and apparently of compulsory specifications), summary judgment or a directed verdict for the defendant

${ }^{37}$ Chock Full O'Nuts Corp., 83 F.T.C. 575, 643-56 (1973).

${ }^{38}$ Susser, 332 F.2d at 515 (judgment for defendant on other grounds); see also Thompson v. Metro. Multi-List, 934 F.2d 1566 (11th Cir. 1991), cert. denied, 506 U.S. 903 (1992). The alleged tying product was a real estate board's multiple listing service by which properties listed with one broker can be sold by any participating broker, thus making a property available to the customers of many brokers. To obtain the alleged tying product (multi-list service), brokers were obliged to join the real estate board (alleged tied product). The board defended the membership requirement as a reasonable way to compel brokers using the multi-list service to abide by the board's solicitation and arbitration rules assuring the integrity of the tying product. The court replied that the participants in the multi-list service could be made to promise to abide by such rules without requiring them to join the board.

${ }^{39}$ Siegel v. Chicken Delight, 448 F.2d 43 (9th Cir. 1971), cert. denied, 405 U.S. 955 (1972); Carpa v. Ward Foods, 536 F.2d 39 (5th Cir. 1976) (seafood products conventionally classified by grade, which franchisor could specify).

${ }^{40}$ Anderson Foreign Motors v. New England Toyota Distrib., 475 F. Supp. 973 (D. Mass. 1979).

${ }^{41}$ Moore v. Jas. H. Matthews \& Co., 550 F.2d 1207 (9th Cir. 1977).

${ }^{42}$ Rosebrough Monument Co. v. Memorial Park Cemetery Assn., 666 F.2d 1130, 1146 (8th Cir. 1981), cert. denied, 457 U.S. 1111 (1982).

${ }^{43} \mathrm{Ibid}$; Moore, supra note 41, at 1217.

${ }^{44}$ E.g., Siegel v. Chicken Delight, 448 F.2d 43 (9th Cir. 1971), cert. denied, 405 U.S. 955 (1972); Warriner Hermetics v. Copeland Refrigeration, 463 F.2d 1002 (5th Cir.), cert. denied, 409 U.S. 1086 (1972) (franchised wholesalers allowed to buy rebuilt compressors only from manufacturer-authorized rebuilders who use manufacturer's parts exclusively); Metrix Warehouse v. Daimler-Benz, 828 F.2d 1033 (4th Cir. 1987), cert. denied, 486 U.S. 1017 (1988). 
has been granted, as in the First Circuit decision allowing a manufacturer of silo unloaders to sell them only to those owning the manufacturer's silo. ${ }^{45}$ Of the 36 unloaders previously sold to owners of other silos, complaints and claims were made on half, and six were returned for refund. The court concluded, "A record of fifty percent dissatisfied customers over a seven-year period [is] a matter too substantial to be disregarded.... Antitrust laws do not require a business to cut its own throat."

Of course, specifications are not an effective alternative when a uniform brand name on the second product is the essence of the arrangement. For example, a McDonald's franchisee argued that in order to obtain the tying franchise, the franchisee was obliged to serve Coca-Cola and no other cola drink. ${ }^{47}$ The court assumed that a tie-in was present but nevertheless gave summary judgment for McDonald's because a uniform, standardized menu was at the heart of the fast-food franchise business model.

Even more clearly, the manufacturer of a brand-name product is entitled to insist that dealers resell only that product under that brand name; dealers may not offer under that name products of equivalent specifications, for the brand name here identifies the manufacturer. ${ }^{5}$ Indeed, the courts uniformly decline to characterize this arrangement as a tie at all. ${ }^{48}$

\section{Voluntary Versus Compulsory Compliance}

Specifications are most likely to suffice in precisely those situations where compliance matters least to the tying seller. When the customer bears virtually all the risk of malfunctions, her own interest will force her to pay attention to the specifications. If she does not, the maker of the machine can be relatively indifferent.

However, even the most precise voluntary specifications do not bind the intermediate customer or diminish its incentives to buy an inferior second product,

\footnotetext{
${ }^{45}$ Dehydrating Process Co. v. A.O. Smith Corp., 292 F.2d 653 (1st Cir.), cert. denied, 368 U.S. 931 (1961).

${ }^{46} I d$. at $656-57$.

${ }^{47}$ Martino v. McDonald's Sys., 625 F. Supp. 356 (N.D. Ill. 1985). Interestingly, the franchisor had no direct financial interest in the Coca-Cola company's sales. However, that company contributed to the franchisees' advertising fund, which was controlled by the franchisor, according to the plaintiff. For the relevance of a "tying" seller's financial interest in the "tied" product, see 9 ANTITRUST III 1726-1727.

${ }^{5}$ See J. THOMAS MCCARTHY, 2 MCCARTHY ON TRADEMARKS AND UNFAIR COMPETITION \$18:2 (4th ed. 1996) ("Good will and its trademark symbol are as inseparable as Siamese Twins who cannot be separated without death to both.").

${ }^{48}$ E.g., Krehl v. Baskin-Robbins Ice Cream Company, 664 F.2d 1348 (9th Cir. 1982); Jack Walters \& Sons Corp. v. Morton Bldg., 737 F.2d 698 (7th Cir. 1984); California Glazed Prods. v. Burns \& Russel Co., 708 F.2d 1423(9th Cir.), cert. denied, 464 U.S. 938 (1983); Redd v. Shell Oil Co., 524 F.2d 1054 (10th Cir. 1975), cert. denied, 425 U.S. 912 (1976).

Trademark law condemns many attempts to disaggregate a trademark from the good to which it is attached. In general, the owner of a trademark is obliged to stand behind the trademarked product. Thus, the law frowns on, although does not entirely eliminate, the "in gross" assignment of trademarks. See HeRBERT HOVENKAMP, MARK D. JANIS, MARK A. LEMLEY, \& CHRISTOPHER R. LESLIE, IP AND ANTITRUST: AN ANALYSIS OF ANTITRUST PRINCIPLES APPLIED TO INTELLECTUAL PROPERTY LAW §2.4 (2d ed. 2009 \& Supp.).
} 
particularly where free riding on other dealers is a valuable possibility. ${ }^{49}$ The manufacturer and consumer are at risk precisely because the intermediary may foolishly or selfishly forgo a superior second product. Voluntary specifications obviously do not compel the intermediary to make a different choice, although they might sometimes educate that firm to make a better choice.

Moreover, specifications would only rarely educate consumers to the point of dissuading them from accepting an incorrectly flavored hamburger, a non-Mercedes replacement part, repair service not in accord with the manufacturer's manual, or a less qualified anesthesiologist. The consumer will not be in position to observe whether the franchisee followed the recipe, nor to understand the specifications governing auto parts, service procedures, or anesthesiology or its practitioners.

When voluntary specifications do not adequately serve the tying seller's legitimate interests, the defendant is free to require compliance. IBM is entitled to insist that machine users promise to process only cards meeting its specifications, or the hospital may allow only approved anesthesiologists. Mercedes or fast food franchisors might require their customers to promise to use only parts or recipes meeting the specifications. Jerrold might sell only to cable operators promising to engage installers following the Jerrold manual. ${ }^{50}$ The International Salt Court itself approved of "reasonable restrictions designed in good faith to minimize maintenance burdens and to assure satisfactory operation." 51

\section{Cost and Effectiveness}

An immediate customer's promise to comply adds nothing to voluntary specifications unless the promisee can monitor compliance effectively and economically. In general, administering compulsory specifications is more burdensome than administering a tie.

When a second product (or service) is bundled into the purchase price of a first product, the customer naturally accepts the second product from the tying seller rather than pay additional sums to another supplier. Because the costs of administering a bundled tie are zero, administering any alternative inevitably costs more, probably substantially more. While supervising another's installation would be very costly, examining the results would be cheaper but insufficient to correct faulty installation without costly troubleshooting.

When not bundled into the price of the tying product, a tie has administrative costs of its own, because the customer may "cheat" on a promise to buy the tied product only from the tying seller. However, the seller need only observe a single instance of noncompliance to detect the customer's breach. By contrast, each of the customer's purchases from other sources must be tested to determine whether the customer has followed promised specifications.

\footnotetext{
${ }^{49} \mathrm{~A}$ clear example is the franchisee without significant repeat business, who employs inferior goods because customers rely on the reputation of the franchise as a whole.

${ }^{50}$ During the pioneering stage, however, Jerrold's unwritten experience may be the key to successful installation.

${ }^{51}$ Int'1 Salt Co. v. United States, 332 U.S. 392, 397 (1947).
} 
Consider, for example, a manufacturer who leases a machine or guarantees its performance. When the manufacturer itself provides the machine's supplies, attachments, or services, it remains responsible under any machine warranty and cannot assess the user for deterioration of a leased machine. Otherwise, the manufacturer must determine whether the machine's failure or deterioration was caused by the machine's own defects or by inferior supplies, attachments, or service. Even if such inferiority leaves a readily observable residue, it may be costly to discover it; without that residue, it will be very costly or impossible to learn whether the user fulfilled its promise to use materials or service of specified quality.

Such difficulties multiply for food franchisors or automobile manufacturers. They cannot rely on consumer complaints of inconsistent taste or inferior repair parts, for consumers may simply buy their next sandwich or auto elsewhere rather than bother to document their dissatisfaction in a brief to the franchisor or manufacturer. Even after complaints, investigations are expensive. So are unannounced inspections, which may also be inconclusive to prove substantial breach rather than an occasional lapse. Inspecting the franchisee's kitchen may find the spices being used, although chemical analysis might be needed to determine their composition. Similarly, the auto dealer's repair parts may require complex testing as well as some way to assess a dealer's claim that such parts (if inferior) were demanded by an economizing consumer. Though not insurmountable, such difficulties often mean that the specification alternative is more costly and less effective than a tie to implement a supplier's legitimate interest in quality control.

Conventional skepticism toward the need for a tie to protect quality was expressed by the Fourth Circuit in denying Mercedes, which had required dealers to use its own repair parts, a directed verdict or judgment notwithstanding the verdict. ${ }^{52}$ The jury was allowed to conclude that Mercedes could have assured consumers proper repair parts by requiring dealers to conform to Mercedes specifications and to inform consumers of the source of repair parts that would be installed if consumers did not specifically request Mercedes parts. However, when a jury rejected the alternatives, the Ninth Circuit affirmed judgment for Mercedes. ${ }^{53}$ That court was persuaded by Mercedes that franchised dealers may be tempted to "cut corners" with lower quality repair parts and that it would be burdensome for Mercedes to police each franchisee's compliance with contract specifications on each repair part. Moreover, even if dealers wanted to comply, they could hardly replicate Mercedes' own rigorous testing. ${ }^{54}$

Without Mercedes' reputation for rigorous quality, General Motors' similar claim had

\footnotetext{
${ }^{52}$ Metrix Warehouse v. Daimler-Benz, 828 F.2d 1033 (4th Cir. 1987), cert. denied, 486 U.S. 1017 (1988).

${ }^{53}$ Mozart Co. v. Mercedes-Benz of N. Am., 833 F.2d 1342 (9th Cir. 1987), cert. denied, 488 U.S. 870 (1988).

${ }^{54}$ See also Teleflex Indus. Prods. v. Brunswick Corp., 293 F. Supp. 106 (E.D. Pa. 1968), rev'd on other grounds, 410 F.2d 380 (3d Cir. 1969), which denied a preliminary injunction against a defendant who could probably defend sale of boat engines coupled with instrument panel controls on the ground that effective engine operation depended on properly functioning instruments and that malfunctioning would ultimately damage the engine, for which consumers would blame the defendant.
} 
been rejected by the Federal Trade Commission in $1941 .{ }^{55}$ To the FTC, the restraint seemed too broad in that it embraced parts and accessories whose alleged inferiority would not affect operation of the automobile, GM's warranty obligation, or its goodwill. Moreover, the materials and construction of a large number of the parts made by others were identical to those made by GM. Because that also seemed to be the case for grave markers, a cemetery was not allowed to insist upon supplying all the markers of its graves, although it was responsible for perpetual care. ${ }^{56}$ For the same reason, the Ninth Circuit required a trial for a defendant to show that rivals' seeds were actually inferior to its own. ${ }^{57}$

Finally, quality specifications may not work at all when the quality can be attained only when the "tying" and "tied" goods are assembled as a unit by the defendant itself. For example, in Microsoft ${ }^{58}$ the defendant was accused of tying its Internet Explorer (IE) Web browser to the Windows operating system by commingling the codes of the two programs so that the IE code could not be removed from the operating system code without causing the latter to fail. In this case Microsoft argued that it was not merely the "quality" of the IE browser that was at stake; but also the fact that bundling IE code into the operating system made it easier for third-party software producers to make programs that invoked the Internet as part of their operations. Without passing judgment on the merits of this claim, the court noted that it was "unclear" how the same benefits could be achieved via quality specifications. ${ }^{59}$ As a result, the court concluded the tie in question should be evaluated under a full rule of reason. ${ }^{60}$

\section{Required Use of Approved Providers}

Instead of relying on general specifications that might compromise trade secrets and resist effective monitoring, a defendant might insist that users of the tying product take the second product from "approved sources" (including itself).

To put this discussion in context, note the three ways in which approval of alternative suppliers may be legally relevant. (1) To the extent that customers are able to buy the second product elsewhere, they are not prevented from dealing with competitors of the restraining supplier and therefore do not fall within the literal language of Clayton Act §3 and may therefore not appear subject to a tie-in at all. ${ }^{62}$ (2) To the extent that customers

\footnotetext{
${ }^{55}$ Pick Mfg. Co. v. Gen. Motors, 80 F.2d 641 (7th Cir. 1935), aff'd per curiam, 299 U.S. 3 (1936). An earlier Seventh Circuit decision favored GM on the ground of inadequate anticompetitive effect and was affirmed per curiam by the Supreme Court as not clearly erroneous. See Pick, 80 F.2d 641.

${ }^{56}$ Moore v. Jas. H. Matthews \& Co., 550 F.2d 1207 (9th Cir. 1977).

${ }^{57}$ Betaseed v. U and I, 681 F.2d 1203 (9th Cir. 1982).

${ }^{58}$ See United States v. Microsoft Corp., 253 F.3d 34, 90 (D.C. Cir.), cert. denied, 534 U.S. 952 (2001).

${ }^{59}$ Microsoft, 253 F.3d at 90.

${ }^{60}$ Ibid.

${ }^{62}$ See, e.g., Kentucky Fried Chicken Corp v. Diversified Packaging Corp., 549 F.2d 368, 378-79 (5th Cir. 1977) (requiring restaurant franchisees to purchase food cartons only from ten approved sources, one of which was an affiliate of the franchisor, not a tie because franchisee "not required to buy a single unit of the tied product from the tying party"); Gen. Motors Corp. v. Gibson Chem. \& Oil Corp., 661 F. Supp. 567, 570-71 (E.D.N.Y. 1987) (no tie where GM allegedly required auto purchasers to use Dexron transmission fluid but licensed all qualified suppliers without charge to use that trademark); Miller v. Int'l
} 
can buy the second product elsewhere, there is little danger that the restraining supplier can acquire power in the second market not based on customer preference for its product(and no danger when the defendant does not supply the second product at all). Hence, even the low threshold for illegal effects may not be satisfied here. ${ }^{63}$ (3) Assuming that a tie-in is present and prima facie illegal but that defendant has a genuine quality-control problem, is approval of other sources for the second product a reasonable and preferable way of solving that problem? Only the third issue is considered here.

Approving alternative sources may benefit customers, society, and the tying seller. As compared with tying as a vehicle for quality control, approval allows the restrained customer some choice among suppliers of the second product and thereby reduces the restraint's ability to bring market power to the restraining seller. As compared with voluntary or mandatory specifications, insisting on approved sources can protect quality better while reducing both costs of administration and compromises of trade secrets.

Trade secrets are less at risk because they would be disclosed only to the relatively few firms making the second product rather than to the numerous franchisees or customers using the product. To be sure, every additional disclosure makes a secret less secure, and it is hard to imagine any anti-tying rule that would require, say, Coca Cola to disclose its formula to anyone. With formulas less secret to begin with, limiting disclosure to spice packagers who covenant against further disclosure may suffice to protect a fast-food recipe that is neither very distinctive in fact nor resistant to "reverse engineering."

Approval, moreover, need not rest on any disclosure at all. For example, Mercedes can examine parts made by others, rejecting some and approving others, without disclosing its own manufacturing techniques, materials, or designs-leaving rivals to discover these matters if they can. The question is whether we can identify sham disapprovals in the absence of objective specifications.

Quite apart from the trade-secret problem, insisting that customers use approved sources may protect quality better and at lower cost that monitoring each user's compliance with specifications. The defendant need only discover that the franchisor, dealer, or other customer has patronized an unapproved source rather than examine each product used in order to detect more-than-occasional or minor departures from specifications. In approving alternative sources, moreover, the defendant implements its own specifications and chooses the tolerable degree of noncompliance-a task for which it is probably better qualified than its customer. The other side of the competence coin, however, is sham disapproval, to which we now turn.

\section{Adequacy and Good Faith Implementation}

Notwithstanding its many attractions, approval of alternative sources may be too burdensome to require. The Ninth Circuit affirmed a jury verdict in favor of Mercedes'

Dairy Queen, 1979-1 Trade Cas. I62,593 (D. Minn.) (no tie where franchisor authorized over 100

suppliers nationally and was ready to designate more).

${ }^{63}$ See 9 ANTITRUST II 1726. 
requirement that its franchised dealers use its repair parts even though it might instead have furnished other suppliers with design specifications for those products. ${ }^{64}$ Mercedes would presumably have to test the products of other suppliers in the same rigorous way it tests its own products. "Designating particular suppliers ... requires policing compliance at the manufacturer level, which may be just as difficult as at the franchisee level."65

On the other hand, a hospital's screening of physicians seemed an adequate means of protecting quality. In Jefferson Parish, a hospital staffed its operating rooms exclusively with a certain group of anesthesiologists, explaining that patients benefitted by the exclusion of incompetent doctors. ${ }^{66}$ Regarding this arrangement as a tie of anesthesiologists to operating rooms, the court held the tie unnecessary. The hospital could take the less restrictive course of screening anesthesiologists and allowing only the competent ones to practice at the hospital. The hospital had apparently not proved that such an alternative method of screening was significantly less effective or more costly.

When approvals are practicable in principle, the defendant still cannot be faulted for the mere absence of numerous (or even any) such approvals. ${ }^{67}$ Customers or rivals may not have sought approvals, or no rival product may be good enough. On the other hand, an approved-supplier option for customers might be entirely fictitious.

In any event, the test of an approved-source option is not the existence or number of current approvals but the defendant's readiness in good faith to examine rival products and to approve the qualified ones. ${ }^{68}$ Courts have approved contractual restrictions

\footnotetext{
${ }^{64}$ Mozart Co. v. Mercedes-Benz of N. Am., 833 F.2d 1342 (9th Cir. 1987), cert. denied, 488 U.S. 870 (1988).

${ }^{65} \mathrm{Id}$. at 1342. In an earlier suit by the government, Mercedes was denied summary judgment because it had not proven that other manufacturers did not supply parts of equivalent quality or that it could not practicably and rigorously inspect rival products. United States v. Mercedes-Benz of N. Am., 517 F. Supp. 1369 (N.D. Cal. 1981). That suit was ultimately dismissed by the government. 547 F. Supp. 399 (N.D. Cal. 1982); see also Metrix Warehouse v. Daimler-Benz, 828 F.2d 1033 (4th Cir. 1987), cert. denied, 486 U.S. 1017 (1988).

${ }^{66}$ Hyde v. Jefferson Parish Hosp. Dist. No. 2, 686 F.2d 286 (5th Cir. 1982), rev'd on other grounds, 466 U.S. 2 (1984).

${ }^{67}$ In Polytechnic Data Corportation v. Xerox Corporation, 362 F. Supp. 1, 8 (N.D. Ill. 1973), a machine lease forbade attachments not tested and listed by Underwriter's Labs. Xerox demonstrated good faith by providing an interface for attachments made by others. Although that interface was the only one approved by UL, according to the plaintiff, the requirements were exactly what various local governments had placed into electrical codes, and the plaintiff did not accept the opportunity to conform. A tie-in had not been adequately pleaded, and "[i]t is clear ... that there is no antitrust violation in adopting and implementing a policy which is designed to promote safety, protect the integrity of one's property or goodwill or assure proper functioning of equipment."

${ }^{68}$ See Photovest Corp. v. Fotomat Corp., 606 F.2d 704 (7th Cir. 1979), cert. denied, 445 U.S. 917 (1980). At one time, the defendant Fotomat required its franchisees to purchase their photo-processing services from the defendant or from approved sources in which the defendant had no financial interest. Although the defendant provided no list of approved processors, the court found no tie-in: "Given the contractual language, which at least provides for the possibility of purchasing processing from non-
} 
limiting customers to approved sources when approval is not "unjustifiably withheld" 69 or when the contract forbids the franchisor from "unreasonably withholding" approval. ${ }^{70}$ Of course, it will sometimes be difficult to distinguish good faith from subterfuge. ${ }^{71}$

\section{Inspection Fees}

The defendant may require reimbursement from customers or rivals for its reasonable costs of inspecting and later reinspecting the rival product. Reasonable inspection fees are permissible because no one should be forced to perform services for another without compensation for the property, energy, time, or other resources thereby consumed. Let us consider whether this axiom is overcome by one practical or one conceptual argument.

First is the practical assertion that allowing the fee would burden access to equivalent products more than disallowance would burden defendants. It seems undeniable that allowing inspection fees creates an opportunity to delay inspection through negotiation or to demand excessive fees that make the approved-supplier option a charade. Hence, allowing such charges will burden access. Were inspection costs de minimis, judicial convenience might warrant imposing them upon the defendant to induce defendants to think twice before imposing any restraint and to save plaintiffs and antitrust tribunals the burden of distinguishing reasonable fees from de facto refusal to approve others. However, inspection costs will not always be so minor.

Second is the conceptual argument that disallowing inspection fees does not expropriate defendant's resources on behalf of customers or rivals because inspecting a rival product's quality is seen primarily to serve the defendant itself. After all, the rationale for allowing any defense for quality control is that the restraint serves the defendant's legitimate interest in maintaining the quality and goodwill of its tying product. While inspecting rival products may not be the defendant's preferred method of assuring the reputation of its tying product, such assurance undoubtedly serves the defendant's own interests.

Although this is true, an overly aggressive anti-tying law is what often coerces the use of an approved-source option. The issue arises only after the defendant establishes a prima facie justification that the challenged tie effectively promotes product quality. In rebuttal, it is the plaintiff who insists that approved sources would protect quality as well and less restrictively. To accept that rebuttal, the tribunal must conclude that the

Fotomat sources, we are reluctant to find a tying arrangement without some evidence that Fotomat applied the contract language so restrictively as to constitute a de facto tying clause." Id. at 722 .

${ }^{69}$ Smith v. Denny's Rest., 62 F.R.D. 459 (N.D. Cal. 1974) (no tie unless approval "unjustifiably withheld").

${ }^{70}$ Kentucky Fried Chicken Corp. v. Diversified Packaging Corp., 549 F.2d 368, 378 (5th Cir. 1977) (no tie).

${ }^{71}$ For example, in Ohio-Sealy Mattress Manufacturing Company v. Sealy, 585 F.2d 821, 836 (7th Cir. 1978), cert. denied, 440 U.S. 930 (1979), the court gave relatively little weight to contractual provisions for approval of other suppliers and the absence of evidence that the defendant had ever denied any approval. The only approved firms were the defendant's subsidiaries and two other firms that, the jury might find, had paid commissions to the defendant for the privilege of being approved. 
proposed alternative restrains competition much less, protects quality as well, and does not burden the defendant with significant costs.

If such costs are significant, we would not impose them on the defendant merely because the alternative restraint protects the quality of its tying product. Threatened with "Your money or your life," handing over one's wallet serves one's own interest. Somewhat similar is the defendant who is told "to inspect rival products without charge or give up the goodwill you have in the tying product." That the defendant would rather do the former than the latter does not warrant imposing those costs upon it.

Of course, permitting such charges creates an opportunity for abuse. Unduly high fees, unnecessarily intensive inspection, or too frequent re-inspections could be so burdensome as to discourage any requests or make any approved rivals noncompetitive. Actual costs (including the opportunity costs of any resources involved) are the appropriate measure, and the defendant should bear the burden of proving these costs.

\section{Access Fee $\mathrm{Fe}^{72}$}

May the defendant charge other suppliers of the tied product a fee for the privilege of access to the tied customers without losing a prima facie quality-control justification that it might otherwise have? A negative answer is the simplest and the one most consistent with the cases applying present doctrine. First, once a restraint is declared per se or prima facie illegal, with quality control seen as an affirmative justification, the scope of the justification limits the permissible restraint. Obviously, the restraint with an approval fee goes beyond that justification, and the finding of prima facie analysis amounts to a holding that the defendant has no general entitlement to restrict its customers' access to rival suppliers and thus has no entitlement to sell them access to the tied customers. Second, though an approval fee can protect quality while generating incremental profit, it might provide an independent motive for the defendant's tie and thus undermine the defendant's sincerity in claiming that it protects quality better than non-tying alternatives. Hence, administrative convenience in supervising litigation reinforces the first reason for rejecting a quality-control defense when the defendant charges merely for access to the tied customers.

The Seventh Circuit thought it was confronted with such a fee and rejected it. ${ }^{73}$ The defendant controlling the Sealy mattress trademark required licensees making mattresses to use a "Posturegrid" element, which is a patented product of Universal Wire, which "paid to Sealy a charge of from three to five percent of their sales to the licensees, unbeknownst to the licensees." 74 Although the Posturegrid might have been important to the quality of the trademarked product, concealment of the rebates

\footnotetext{
${ }^{72}$ See 9 ANTITRUST 1 1727d for a different question: If the tying seller's only interest in the tied market is an access fee or commission from the seller of the tied product, is the tie covered by the socalled per se rule against tying? If not, a defense for quality control would not ordinarily be in issue.

${ }^{73}$ Ohio-Sealy Mattress Mfg. Co. v. Sealy, 585 F.2d 821 (7th Cir. 1978), cert. denied, 440 U.S. 930 (1979).

${ }^{74} I d$. at 833 . The specifications also included several components from approved suppliers (including Sealy subsidiaries) who paid similar royalties to Sealy.
} 
suggested otherwise, and the jury could have believed "that Sealy forced the use of the Posturegrid and was paid handsomely by Universal simply for creating a captive market in which it could and did charge a premium price." 75

Nevertheless, this easy negative answer is overly simple. We must look behind the fact of prima facie illegality to its rationale. If the rationale is the fact or danger of substantial foreclosure disrupting the vitality of competition in the second market rather than incremental profit for the defendant, those dangers need not be (and usually are not) increased by an approval fee. An approval fee works either to charge customers according to their volume of tied purchases ${ }^{76}$ or to appropriate some excess profits from suppliers of tied products. ${ }^{77}$ These effects are not grounds for condemning ties ${ }^{78}$ and have not been the central concerns of existing doctrine. ${ }^{79}$

Thus, the treatment of approval fees depends on both the underlying rationales for condemning tie-ins and on the severity of that prohibition. Existing doctrine refuses to confine anti-tying rules closely to dangerous foreclosures and regards defenses as narrow and exceptional. In that context, approval fees tend to defeat a quality-protection affirmative defense. If and when doctrine is reformed to focus heavily on the magnitude of the foreclosure, then approval fees become legally irrelevant except to whatever extent they might possibly impair the vitality of competition in the tied market.

\section{Number of Approvals}

Much of what has just been said applies also to the number of approvals. Of course, the least intrusive solution of a genuine quality-control problem allows customers to take the tied product from numerous alternative sources. So long as an insubstantial share of the tied market is foreclosed, the only detriment flowing from fewer approvals is that the alternative sources might be so few as to behave noncompetitively. The tied customers might therefore be denied the benefits of fully competitive prices on the tied product standing alone, as just discussed in connection with approval fees.

Given the hostility of existing doctrine, which regards justifications as exceptional and denies any general entitlement to restrict access to the tied customers, a quality control defense would not save an exclusion of qualified suppliers. Thus, unless the number of approvals itself defeats prima facie illegality by negating a tie's existence or effects, a defendant justifying an otherwise illegal tie on the ground of approved alternative sources cannot limit their number as such.

\footnotetext{
${ }^{75}$ Sealy, 585 F.2d at 835. The court added, "Even if the Posturegrid was a superior product, such an arrangement was unlawful." Ibid. That is, Sealy would still be collecting a commission for allowing access to the tied licensees, not for any secret or patent that Sealy owned. Indeed, Sealy officials had referred "to the charge as a royalty for the privilege of supplying Sealy licensees" or "as a royalty, a commission, or a load charge." Id. at 834 n.20.

${ }^{76}$ See 9 ANTITRUST II 1711b1.

${ }^{77}$ See 9 AnTITRUST II 1715f.

${ }^{78}$ See id. at III 1710-1715.

${ }^{79}$ See id. at II 1704.
} 


\section{Protection or Misuse of Trade Secrets}

\section{The Problem}

Requiring specifications as a less restrictive alternative can burden suppliers with another cost that is seldom, if ever, noted in the decided cases: uncompensated disclosure of trade secrets. Can Colonel Sanders disclose his "secret recipe" for Kentucky Fried Chicken to hundreds (or thousands) of franchisees without effectively putting it in the public domain and thereby losing its exclusive use? Or consider Coca Cola's syrup formula. If a tie-in of bottling franchises to the syrup were alleged, should an otherwise acceptable quality-control defense be denied on the ground that the defendant had the alternative of disclosing the syrup formula to all its franchiseedistributors? Can a machine maker supply highly detailed service manuals to its customers without giving away proprietary trade secrets concerning the details of the machine's construction and operation?

Recall the computer maker burdened with the costs of discovering and correcting malfunctions in its guaranteed software when used with other computers not completely identical to its own. ${ }^{80}$ Rather than require its software customers to buy their computers from it, the defendant might, the court suggested, publish the details of its computers so that rivals could copy them exactly.

Four issues arise. First, is a real and significant trade secret at stake? Second, would disclosure have the effect of putting a trade secret into the public domain, thereby destroying its value? If so, it should not be deemed a less restrictive alternative that defeats an otherwise available quality-control defense to a tie-in. Third, if disclosure is otherwise appropriate, may a defendant charge a royalty for the disclosure? The answer should be affirmative. Fourth, even if the secret can be maintained and charged for, should disclosure be required?

\section{Actual and Continuing Secret}

Consider whether there is any significant secret that would be lost by providing specifications to customers - focusing on the recipe of a franchisor like Colonel Sanders and on the service manual of a machine maker. In each instance, do trade secrets exist, have they already been compromised, and would covenants against disclosure protect them?

Because trade secrets include everything useful to one firm but unknown to its rival, they are everywhere in some degree. Notwithstanding other motives, therefore, a tying seller may glibly claim that using specifications to protect product quality would destroy a trade secret. Such a claim is sometimes a transparent subterfuge. For example, a chicken recipe may not be secret at all when franchisees observe or consumers taste one bay leaf, five peppercorns, and a dash of marjoram. In such a case, solicitude for trade secrets cannot itself defeat the specifications alternative to the tie as a means of protecting product quality. On the other hand, few would doubt the secrecy and

\footnotetext{
${ }^{80}$ See Data Gen. Corp. Antitrust Litig., 490 F. Supp. 1089 (N.D. Cal. 1980) (defense not established), ultimately condemned, 734 F.2d 336 (9th Cir. 1984), cert. denied, 473 U.S. 908 (1985).
} 
importance of Coca Cola's syrup formula. In intermediate situations, the tribunal must consider evidence about knowledge outside the company of the alleged secret or about the relative ease with which outsiders can lawfully discover the secret by merely examining the product or otherwise. The defendant company itself may have spread knowledge of a one-time trade secret so far that rivals know or can easily discover it, such that it is no longer a secret. Suppose, for example, that a machine maker has already provided a detailed service manual-which it now claims discloses secrets about the construction and operation of its machine-to 5,000 installers and repairers. Can something really be secret when 5,000 people know it? Even if they are all sworn to secrecy, loose talk and lost manuals tend to spread knowledge, at least when others seek it out.

Such a machine maker faces an additional obstacle. It might argue that tight security with the documents and covenants against employee disclosure have in fact preserved the secrets of its machine's construction and operation. That claim may imply that similar security and covenants would preserve secrecy when specifications are spread more widely, although outsiders may feel less loyalty to the defendant than its own employees.

\section{Royalties}

If the defendant makes trade secrets available to customers in place of a tie or to rivals to enable them to supply tied customers-either because it chooses to do so or because it will otherwise be condemned for tying illegally-it is clearly entitled to charge a fee for the disclosure, such as a share of the rival's revenues from sales benefitting from the disclosure. The problem, of course, is that such a fee may disguise a forbidden approval royalty when no real secret has been disclosed or a single-source tie when the fee exceeds the value of the disclosure.

Because the tying seller might plausibly have some tying- or tied-product knowledge useful to an outside supplier of the tied product, a sham trade secret license will appear genuine. When tied customers can profitably be charged a premium above the perfectly competitive price for the second product, other suppliers would be willing to pay for access to them-perhaps almost as much as the full premium itself. Such suppliers will thus buy a "license" for a "trade secret" they know to be fictitious or trivial. Such a license is nothing more than a sham for the payment of a forbidden approval fee, although it cannot easily be distinguished from the license of a genuinely valuable trade secret.

The existence of such a secret does not end the tribunal's problems. The royalty might still exceed its value and thus extract a mere approval fee for access to the tied customers. Or it might so exceed the value of the secret or access as, in effect, to be a refusal to approve anyone. In the latter event, the alternative-source option is itself a fiction. This brings us to an antitrust topic that attracts confusion: the "reasonable royalty." Although the quoted phrase hints at competitive level returns, the holder of a valuable secret or patent is entitled to the full value that the market places upon it. This is clearest in the case of patents, which are government grants designed to guarantee 
their monopoly value to the inventor. ${ }^{81}$ That other holders of property are also entitled to its market value is demonstrated by the routine holding that an otherwise lawful monopolist does not violate the antitrust laws by charging the monopoly price. ${ }^{82}$ To the extent, if any, that anti-tying law requires one to make trade secrets available to others, the rationale is the avoidance of undue foreclosure, not the expropriation of trade secrets.

\section{Conclusion: Trade Secrets Protected}

Once a tie is determined to serve the legitimate interest of protecting product quality, such a defense should not be rejected on the ground that the defendant has available a less restrictive alternative of giving away a valuable trade secret. Tying doctrine would be very severe indeed if it refused to recognize a legitimate business problem on the grounds that the firm can solve it by surrendering its trade secrets without full compensation. Even if appropriate compensation can be guaranteed, it seems doubtful that disclosure of a trade secret should be required at all. The rationale for objecting to a tie-in in the first place is that it excludes producers of equivalent second products. If there are no such producers, there is no exclusion. Nothing in tying doctrine requires the tying seller to create rival suppliers by instructing them what to make (specifications) or how to make it (secret know-how).

Thus, the proper role of specifications as an alternative to tying is solely to instruct customers how to protect the quality of the tying product by using a second product that other suppliers already make or can readily make without the aid of the tying seller. The problem, of course, is that without additional information the customer may not be able to tell which rival product is the equivalent of the tying seller's second product. The courts that have insisted upon disclosing such information to customers or rivals have not addressed the trade secret issue, probably because no significant secret appeared to be present.

\footnotetext{
${ }^{81}$ See 10 ANTITRUST $\llbracket 1782 \mathrm{~b}$.

${ }^{82}$ See 3A ANTITRUST II 720.
} 